\title{
Stomach Content Analyses of Simulium perflavum Roubaud 1906 (Diptera: Simuliidae) Larvae from Streams in Central Amazônia, Brazil
}

\author{
Yamile B Alencar ${ }^{+}$,Thelma A Veiga Ludwig*, Climéia C Soares**, \\ Neusa Hamada
}

\begin{abstract}
Coordenação de Pesquisas em Entomologia **Coordenação de Pesquisas em Biologia de Água Doce, Instituto Nacional de Pesquisas da Amazônia, Caixa Postal 478, 69011-970 Manaus, AM, Brasil *Laboratório de Ficologia, Departamento de Botânica, Universidade Federal do Paraná, Curitiba, PR, Brasil
\end{abstract}

Stomach contents of Simulium perflavum Roubaud larvae were analyzed and compared with plankton and periphyton collected in five streams, in Central Amazonia (Manaus and Presidente Figueiredo counties), in Sep./Oct.1996 (dry season) and Feb./Mar. 1997 (rainy season). A total of 1,400 last-instar larvae were dissected; the stomach contents were analyzed using different methods: fresh and after oxidation. A total of 87 taxa (algae, diatoms and rotifers) were found in the stomach contents. In each stream, qualitative samples of plankton and periphyton were collected; these were mounted between slides and cover slips. A total of 94 taxa of plankton and 54 taxa of periphyton were collected. One species of Rotifera was present in the stomach contents, plankton and periphyton. Cluster analysis based on species composition of the organisms present in the stomach contents grouped the streams into two major groups, each belonging to a different drainage area. Correlations based on presencelabsence of species of microalgae in the stomach contents, plankton and periphyton indicated significant associations $(p<0.05)$ between stomach contents and plankton and between plankton and periphyton $(z$ test); the Sorensen coefficient and cluster analysis corroborate the same associations.

Key words: aquatic insects - black fly - diatoms - microalgae - stomach contents - Amazônia - Brazil

Black fly larvae usually are abundant in running-water ecosystems and very important in the food chain because they process fine particulate organic matter making it available for other insects and fishes (predators). The size of particles ingested by black fly larvae is a factor influencing the effects of particulate insecticides on these larvae and on other organisms that live in the same habitat (Lacey \& Lacey 1983). Knowing the minimum dimensions of particles ingested by the larvae can help in choosing the minimum dimensions of insecticides and microorganisms to be maintained in suspension in the water (Lozovei 1989).

Few studies of black fly larval feeding have been done in Brazil. Lozovei (1989) observed 118

\footnotetext{
This study received partial financial support from PPGBTRN/INPA, PPI-2-3230 (INPA/MCT) and CNPq. ${ }^{+}$Fellowship from CNPq (139761/96-9) and corresponding author. Fax: +55-92-643.3195

E-mail: yamile@inpa.gov.br

Received 16 June 2000

Accepted 10 October 2000
}

species of diatoms (Bacillariophyta) in the larval stomach contents of three species of black fly, Dellome Filho (1989) reported 50 genera of Bacillariophyta, Chlorophyta, Cyanophyta and Euglenophyta in the stomach contents of Simulium incrustatum Lutz, 1910 larvae. Lacey and Lacey (1983) observed that food takes $29.2 \mathrm{~min}$ to pass through the intestine of Simulium fulvinotum Cerqueira \& Nunes de Mello (= Simulium rorotaense Floch \& Abonnenc) in an Amazonian stream with a velocity of $1 \mathrm{~m} / \mathrm{s}$ and $0.37 \mathrm{mg} / \mathrm{l}$ particles in suspension.

Some authors (e.g. Craig 1977, Kurtak 1979) studying the feeding behavior and the functional morphology of black fly larvae have suggested that they are grazing and filter feeding. Wotton (1980) and Fredeen (1964) observed large amounts of bacteria in the stomach contents of black fly larvae.

This is the first study on the stomach contents of black fly larvae in the northern region of Brazil. The study identifies the organisms in the stomach contents of S. perflavum larvae and compares them with the plankton and the periphyton present in the streams. The five streams are compared with each other based on stomach contents of black fly larvae. 


\section{MATERIALS AND METHODS}

This study was carried out in five streams in Central Amazônia, three of which were located in the area of the BR-174 highway, Manaus county and two in Presidente Figueiredo county $\left(2^{\circ} 39^{\prime} \mathrm{S}\right.$ $60^{\circ} 2^{\prime} \mathrm{W} ; 2^{\circ} 23$ 'S $59^{\circ} 59^{\prime} \mathrm{W} ; 2^{\circ} 29^{\prime} \mathrm{S}, 60^{\circ} 1^{\prime} \mathrm{W} ; 2^{\circ} 2$ ' $\mathrm{S}$, $59^{\circ} 59^{\prime} \mathrm{W} ; 2^{\circ} 2^{\prime} \mathrm{S}, 5^{\circ} 52^{\prime} \mathrm{W}$, respectively) (Fig. 1). These streams have many characteristics in common: all flow through yellow latosol soil and are located in areas that have been disturbed due to the opening of highways.

In the Manaus area the year can be divided into two seasons: a rainy season from Dec. to May (Mar. being the rainiest month with an average of 281 $\mathrm{mm}$ ), and a dry season from Jun. to Nov. (Aug. being the month with the lowest precipitation, with an average of $39 \mathrm{~mm}$ ) (Araújo 1970). The samples were taken during two months of the dry season (Sep./Oct. 1996) and two months of the rainy season (Feb./Mar. 1997). In each stream, measurements were made of water conductivity (ColeParmer conductivimeter), temperature (mercury thermometer) and $\mathrm{pH}$ (Cole-Parmer $\mathrm{pH}$ Testr 2).

Black fly stomach contents were analyzed using two different techniques. Seventy larvae from each stream were dissected monthly during the study period; from this total 20 larvae were maintained alive on ice, transported to the laboratory and dissected on the same day, two slides were mounted with the larval black fly stomach contents using glycerine jelly (Lozovei \& Luz 1976), each slide contained the stomach contents of 10 larvae. The remaining 50 larvae were preserved in Carnoy (3 parts absolute ethanol: 1 part glacial acetic acid) or $80 \%$ ethanol for later dissection and treatment using the slow-oxidation technique (Moreira Filho \& Valente Moreira 1981); permanent slides were mounted using Hyrax (I.R = 1.7) as the mounting medium.

Permanent and semi-permanent slides were examined under a Zeiss compound microscope. The organisms present on these slides were counted over the whole field of the coverslip at 40x and 100x.

Plankton were collected using a net with $20 \mu \mathrm{m}$ mesh during $30 \mathrm{~min}$. The samples were placed in $40 \mathrm{ml}$ vials and preserved in Transeau solution (1:1 proportion). Periphyton were collected in the streams from submersed leaves used as substrate by larvae. The material was removed with a brush, placed in $120 \mathrm{ml}$ plastic vials and preserved in Transeau solution.

Identifications of Cyanophyta, Euglenophyta, Dinophyta and Chlorophyta were based on Bourrely (1968, 1970, 1972). The identifications of Bacillariophyta (diatoms) were based on Husted (1930), Krammer and Lange-Bertalot (1985, 1986,

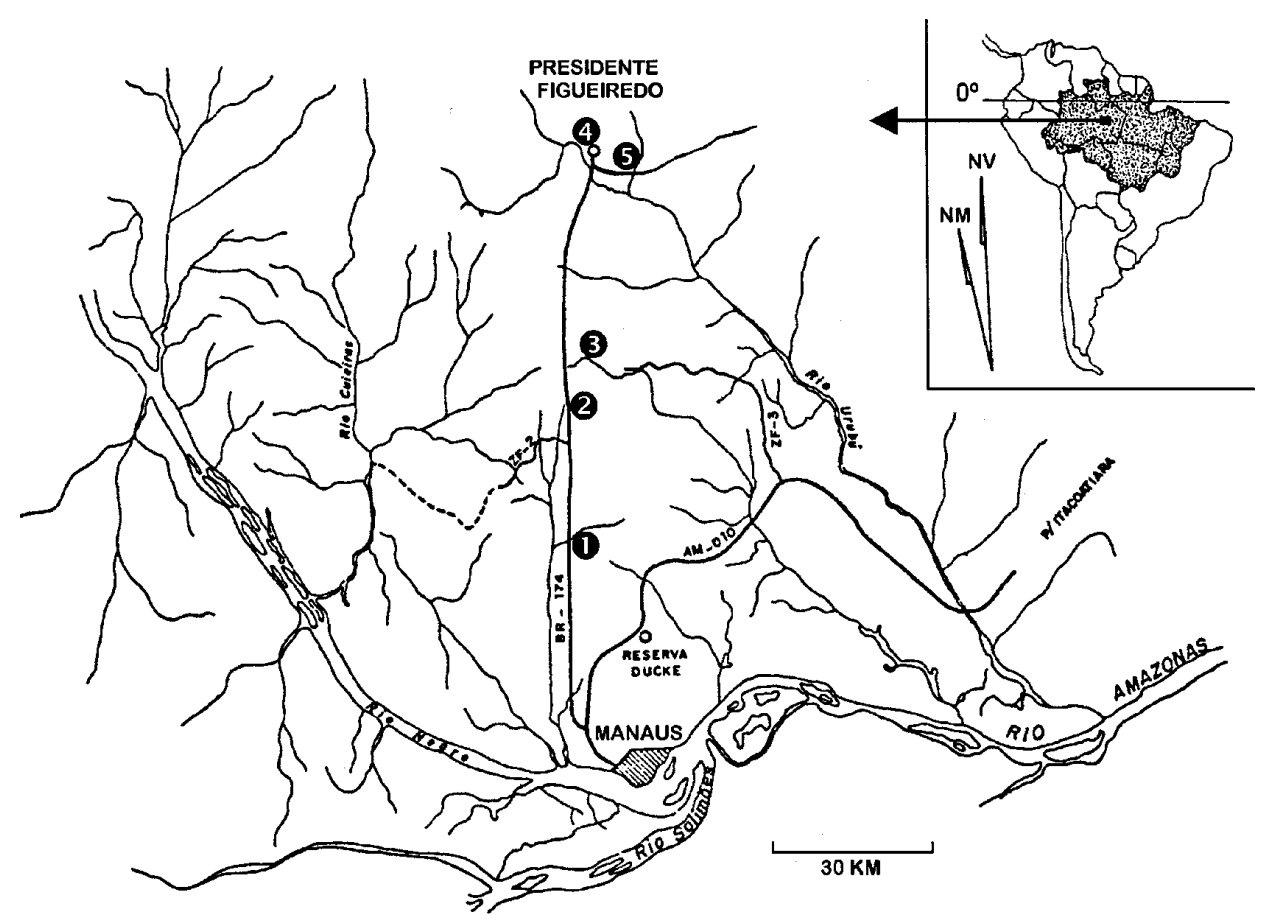

Fig. 1: collection places in Manaus and Presidente Figueiredo counties, Amazonas, Brazil. 1: Ibama stream; 2: Bueiro stream; 3: ZF3 stream; 4: Cemitério stream; 5: Escada stream 
1988, 1991a,b), Kobayasi and Nagumo (1988), and Cox (1996).

Vouchers of $S$. perflavum (larval carcasses) were deposited in the invertebrate collection of the Instituto Nacional de Pesquisas da Amazônia (INPA). Samples of plankton and periphyton and the permanent and semi-permanent slides with stomach contents were deposited in the INPA and the Universidade Federal do Paraná (UFPR).

Similarity patterns based on species present in the three levels (i.e. plankton, periphyton and stomach contents of $S$. perflavum larvae) were verified using the Sorensen coefficient based on presence/ absence data. Sorensen coefficient $=2 A / 2 A+B+$ $\mathrm{C}$, where $\mathrm{A}=$ number of species common to the two levels, $\mathrm{B}=$ number of species exclusive to level 1 , and $\mathrm{C}=$ number of species exclusive to level 2 . The significance of correlation among the three levels was tested using the $\mathrm{z}$ statistic, based on nominal data (Zar 1996). Similarity dendrograms from the similarity matrix with the Sorensen coefficient (binary data) were derived using UPGMA methods (non-balanced means) based on Pielou (1984).

\section{RESULTS AND DISCUSSION}

The streams in the study area had $\mathrm{pH}$ values of 4.4 to 5.3 , conductivities of 9.4 to $12.6 \mathrm{~S} / \mathrm{cm}^{2}$ and temperatures of $25^{\circ}$ to $29^{\circ} \mathrm{C}$, these being representative values of streams in the study, which are normally acidic and poor in mineral salts (Sioli 1965).

S. perflavum larvae feed on diatoms, algae and other organisms present in the plankton and periphyton (Figs 2-72). In the stomach-content analyses (permanent slides), during the dry and rainy seasons 40 species of diatoms were observed; the frequencies of occurrence are presented in Table I.

The Bueiro, ZF3 and Cemitério streams had Peronia sp. as the most frequent diatom species in the dry season $(35 \%, 22 \%$ and $23 \%$, respectively). In the rainy season, the most frequent diatom species were different in these three streams; in the Bueiro stream the most frequent species was Frustulia crassinervia (24\%), in the ZF3 stream it was Eunotia gibbosa (66\%) and in the Cemitério stream it was Actinella brasiliensis and Eunotia conversa (18\% and $17.9 \%$, respectively). The Escada stream had E. gibbosa as the most frequent diatom species in the dry and rainy seasons $(21 \%$ and $14 \%$, respectively). The Ibama stream had $F$. crassinervia as the most frequent species in the dry season (24\%) and E. bilunaris in the rainy season $(44 \%)$.

Species of Actinella and Eunotia are indicators of acidic waters (Patrick \& Reimer 1966). By the frequent presence of these two genera in the stom- ach contents of $S$. perflavum larvae we can characterize the breeding place of this black fly species as being tropical, oligotrophic, acidic waters.

The semi-permanent slides with the stomach contents of $S$. perflavum larvae had a predominance of non-silicose algae. A total of 42 species of non-silicose microalgae were identified, six species of diatoms and one species of Rotifera, Lecane (Monostyla) quadridentata Ehrenberg (Table II). Oedogonium sp. was the most frequent species in the Bueiro stream in the dry and rainy seasons $(70.8 \%$ and $74.3 \%$, respectively). In the ZF3 stream, the most frequent species in the dry and rainy seasons was Microspora sp. (44.6\% and 63.1\%, respectively). In the Cemitério stream, Pleurotaenium minutum Ralfs Delp. was the most frequent species in the dry season $(34.6 \%)$ and Pleurotaenium sp. in the rainy season $(27.8 \%)$. In the Escada stream, Microspora sp. was the most frequent species $(47 \%)$ in the dry season and in the rainy season Closterium sp. was the most frequent (28.6\%). In the Ibama stream, Hyalotheca sp. was the most frequent species in the dry and rainy season (53.5\% and $37.6 \%$, respectively).

The dimensions of diatoms observed in the stomach contents of S. perflavum in the five studied streams were between 67.8 and $133.57 \mu \mathrm{m}$ for E. serra Ehrenberg and Stenopterobia curvula (W. Smith) Krammer, respectively. For the other divisions of microalgae, the sizes range from 150 to $608 \mu \mathrm{m}$ (Closterium sp., Mougeotia sp.) and from 65 to $1000 \mu \mathrm{m}$ (Oedogonium sp.) (Burton 1973).

Depending on the classification of the phytoplankton, the size can vary from 2 to $500 \mu \mathrm{m}$. Kurtak (1978) conducted detailed studies on the size and proportion of the ingested particles of black fly larvae and observed a predominance of large particles $(150 \mu \mathrm{m})$ compared to the smaller ones $(5-10 \mu \mathrm{m})$.

A great variety of food items is reported in black fly larval diets: fungal spores and mycelia, silt, detritus, Rotifera, several species of algae and diatoms (Peterson 1956, Kuznetsov 1981). The diatoms may be important food items because they are reported to be the main components of autoctonous periphyton and are constantly removed from the substrate by the water current, becoming abundant in the plankton (Dudley et al. 1986, Thompson 1987).

In this study, the qualitative analysis of the plankton found 94 infrageneric taxa: 53 Chlorophyta, 29 Bacillariophyta, 7 Cyanophyta, 2 Euglenophyta, 2 Rhodophyta and 1 Dinophyta (Table III). In the qualitative periphyton samples taken during the dry and rainy seasons we found 33 species of microalgae, 21 species of diatoms 
and one species of Rotifera, L. quadridentata (Table III).

The similarity patterns based on qualitative data on items in the larval black fly stomach contents, plankton and periphyton were verified with the Sorensen coefficient. The results indicated
$58 \%$ similarity between organisms present in the stomach contents and plankton in the streams, with $41.4 \%$ of the species in common. The similarity between the periphyton and the larval stomach contents was $54 \%$, with $36.8 \%$ of the species in common. The Sorensen coefficient also indi-

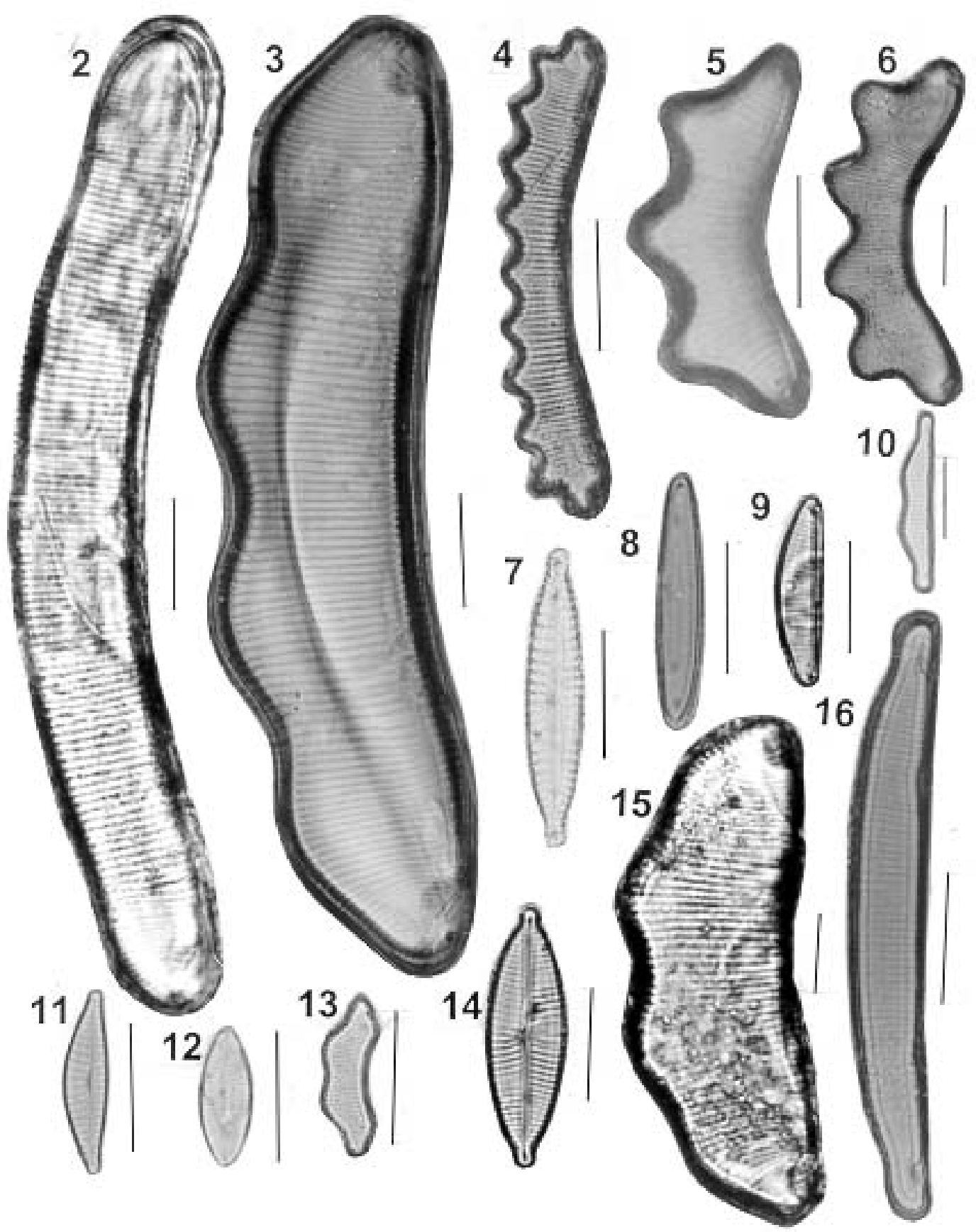

Fig. 2: Eunotia maior. Fig. 3: E. zygodon. Fig. 4: E. serra. Fig. 5: E. triggiba. Fig. 6: E. subrobusta. Fig. 7: Cymbella difficilis Fig. 8: Peronia brasiliensis. Fig. 9: E. minor. Fig. 10: E. bidentula. Fig. 11: C. minuta. Fig. 12: Achnanthes sp. Fig. 13: E. gibbosa. Fig. 14: Cymbella sp. Fig. 15: E. zygodon. Fig. 16: E. sudetica. Bar $=10 \mu \mathrm{m}$ 
cated a $63 \%$ similarity among organisms in the plankton and periphyton with $45.6 \%$ of the species in common.

The hierarchical grouping analyses based on presence and absence with the Sorensen coefficient resulted in $72 \%$ similarity between food items in the larval stomach contents and plankton in the streams, and $67 \%$ similarity between the larval stomach contents and the periphyton (Fig. 73). Therefore, the stomach content items were more

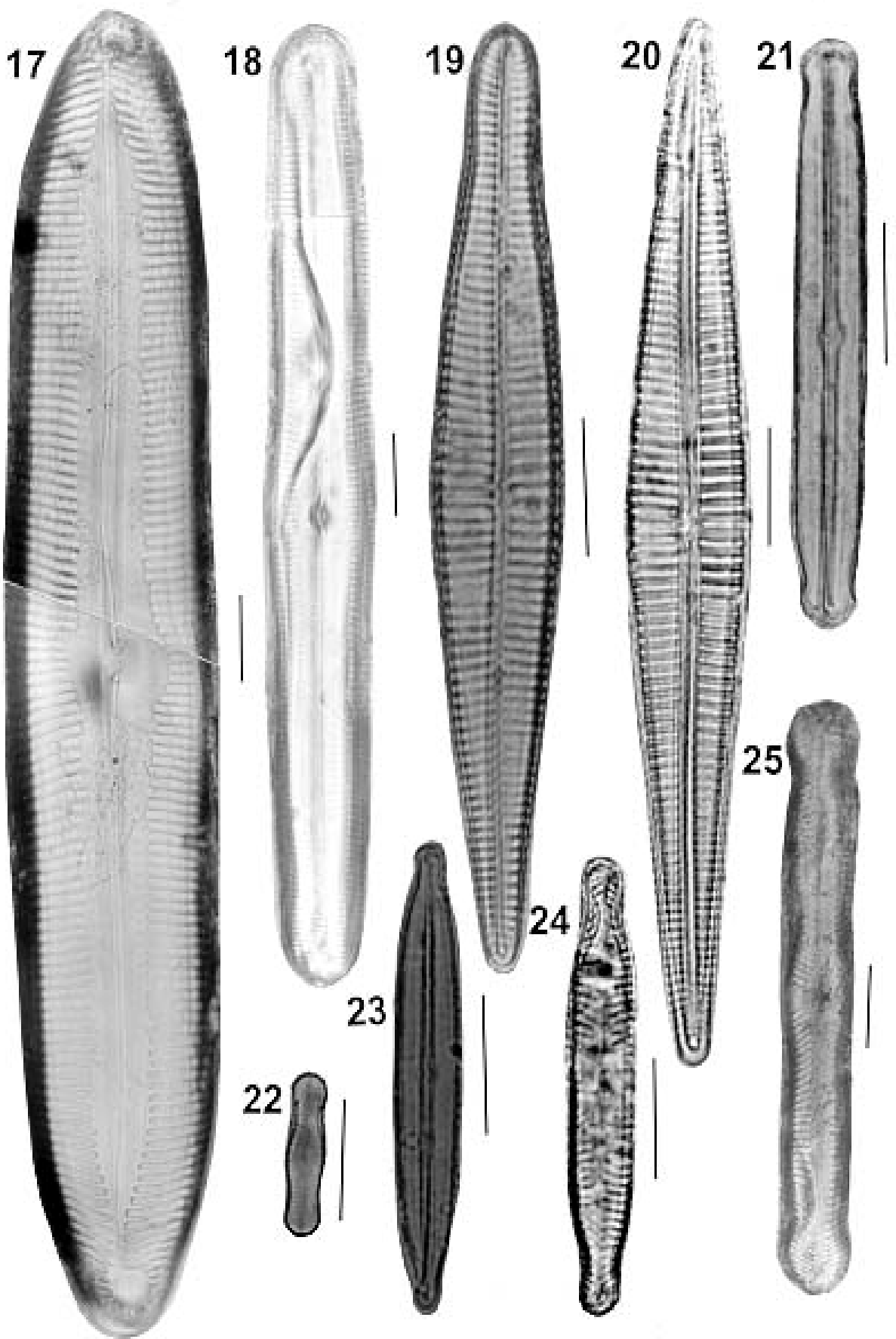

Fig. 17: Pinnularia streptoraphe. Fig. 18: P. maior. Fig. 19: Gomphonema sp. Fig. 20: G. gracile. Fig. 21: Navicula subtilissima. Fig. 22: Navicula sp. Fig. 23: N. parasubtilissima. Fig. 24: P. subcapitata. Fig. 25: Pinnularia sp. Bar $=10 \mu \mathrm{m}$ 
TABLE I

Frequency of diatoms (permanent slides) in the stomach contents of Simulium perflavum (Diptera: Simuliidae) larvae in five streams in Central Amazônia, during the dry (Sep./Oct. 1996) and rainy seasons (Feb./Mar. 1997)

\begin{tabular}{|c|c|c|c|c|c|c|c|c|c|c|}
\hline \multirow[t]{2}{*}{ Diatoms } & \multicolumn{2}{|c|}{ Bueiro } & \multicolumn{2}{|c|}{ ZF3 } & \multicolumn{2}{|c|}{ Cemitério } & \multicolumn{2}{|c|}{ Escada } & \multicolumn{2}{|c|}{ Ibama } \\
\hline & Dry & Rainy & Dry & Rainy & Dry & Rainy & Dry & Rainy & Dry & Rainy \\
\hline Achnanthes sp. & 51 & 40 & 15 & 24 & 40 & 4 & 14 & 37 & 54 & 163 \\
\hline Actinella brasiliensis Grun. & 127 & 145 & 122 & 151 & 180 & 296 & 113 & 309 & 287 & 83 \\
\hline Actinella peronioides Hustedt & 168 & 190 & 77 & 152 & 141 & 2 & 12 & 1 & 226 & 104 \\
\hline Actinella punctata Lewis & 16 & 57 & 5 & - & 8 & - & - & - & 15 & 一 \\
\hline Brachysira kuntzei (Reichelt) & 28 & - & 21 & 150 & 90 & - & 16 & - & 19 & 6 \\
\hline \multicolumn{11}{|l|}{ Metzeltin \& Lange-Bertalot } \\
\hline Brachysira serians (Bréb.) & 122 & 178 & 55 & 4 & 185 & 1 & 54 & 71 & 202 & 115 \\
\hline \multicolumn{11}{|l|}{$\begin{array}{l}\text { Round \& Mann var. } \\
\text { brachysira (Hus.) Cox. }\end{array}$} \\
\hline Brachysira serians (Brébisson) & ) 156 & 177 & 54 & 209 & 232 & 198 & 405 & 1030 & 309 & 192 \\
\hline \multicolumn{11}{|l|}{ Round \& Mann } \\
\hline Brachysira vitrea (Grun.) Ross & 285 & 231 & 182 & 2 & 398 & 5 & 802 & 142 & 336 & 27 \\
\hline Cyclotella sp. & - & 3 & - & 2 & - & - & - & - & - & 1 \\
\hline Cymbella difficilis Krasske & 15 & 3 & 5 & 261 & 43 & 3 & 3,085 & 1,589 & 38 & 38 \\
\hline Cymbella minuta Hilse & 42 & 56 & 38 & 136 & 130 & 9 & 402 & 601 & 74 & 35 \\
\hline Cymbella sp. & - & 1 & 1 & - & - & - & 1 & 3 & 1 & 1 \\
\hline Eunotia bidentula W. Smith & 30 & 41 & 28 & 76 & 32 & 3 & 17 & 40 & 61 & 26 \\
\hline $\begin{array}{l}\text { Eunotia bilunaris } \\
\text { (Ehrenberg) Mills }\end{array}$ & 175 & 574 & 127 & 1148 & 392 & 48 & 648 & 203 & 2,121 & 9,410 \\
\hline Eunotia conversa Hustedt & 301 & 350 & 388 & 230 & 525 & 313 & 376 & 768 & 1,254 & 251 \\
\hline $\begin{array}{l}\text { Eunotia flexuosa } \\
\text { (Brébisson) Kützing }\end{array}$ & 1,548 & 1,870 & 1,200 & 1,584 & 1,769 & 144 & 1,401 & 2,167 & 1,016 & 300 \\
\hline Eunotia gibbosa Grunow & 220 & 251 & 294 & 19,614 & 1315 & 2 & 3,889 & 2,332 & 823 & 274 \\
\hline Eunotia maior (W. Sm.) Rabh. & . - - & - & 1 & - & - & - & - & - & - & 一 \\
\hline Eunotia minor (Kützing) Grunow & W 1 & - & - & - & - & - & - & - & - & 一 \\
\hline Eunotia serra Ehrenberg & 2 & - & 4 & 14 & 7 & - & 18 & 33 & 4 & 2 \\
\hline Eunotia sudetica $\mathrm{O}$. Müller & 106 & 57 & 125 & 224 & 209 & 38 & 390 & 37 & 70 & 21 \\
\hline Eunotia trigibba Hustedt & 2 & - & 5 & 32 & 5 & 2 & 9 & 6 & 7 & 4 \\
\hline Eunotia zygodon Ehrenberg & 1 & 3 & 2 & 38 & 35 & - & 266 & 345 & 3 & 4 \\
\hline Fragilaria javanica Hustedt & 7 & - & 8 & - & 5 & 1 & 30 & 70 & - & - \\
\hline Frustulia crassinervia (Bréb.) 1 & 1,555 & 2,280 & 939 & 750 & 1,632 & 188 & 718 & 1,242 & 3,116 & 3,077 \\
\hline \multicolumn{11}{|c|}{ Lange-Bertalot \& Krammer } \\
\hline $\begin{array}{l}\text { Frustulia rhomboides } \\
\text { (Ehrenberg) De Toni }\end{array}$ & 53 & 81 & 63 & 574 & 383 & 87 & 1,102 & 1679 & 471 & 161 \\
\hline Gomphonema gracile Ehrenberg & 104 & 62 & 325 & 1920 & 580 & 1 & 482 & 316 & 253 & 154 \\
\hline Gomphonema sp. Ehrenberg & 36 & 8 & 48 & 47 & 15 & - & - & 25 & - & 29 \\
\hline Navicula cryptocephala Kützing & 497 & 505 & 321 & 127 & 1,312 & 113 & 420 & 941 & 678 & 311 \\
\hline $\begin{array}{l}\text { Navicula parasubitilissima } \\
\text { Kobayasi \& Nagumo }\end{array}$ & 1 & - & - & - & - & 一 & - & - & - & - \\
\hline Navicula subtilissima Cleve & 112 & 59 & 67 & 21 & 126 & 56 & 140 & 153 & 131 & 48 \\
\hline Peronia brasiliensis Hustedt 3 & 3,156 & 2,124 & 1,552 & 302 & 2,865 & 62 & 920 & 1,203 & 1,095 & 170 \\
\hline Pinnularia maior (Kützing) & 10 & 12 & 21 & 63 & 41 & 21 & 56 & 12 & 50 & 2 \\
\hline \multicolumn{11}{|l|}{ Rabenhorst } \\
\hline Pinnularia sp. & 15 & 32 & 17 & 20 & 27 & 55 & 28 & 74 & 7 & 36 \\
\hline Pinnularia streptoraphe Cleve & 85 & 16 & 47 & 76 & 152 & 1 & 13 & 18 & 90 & 7 \\
\hline Pinnularia subcapitata Gregory & $\mathrm{ry}-$ & - & 1 & - & - & - & - & - & - & - \\
\hline $\begin{array}{l}\text { Stenopterobia curvula } \\
\text { (W. Smith) Krammer }\end{array}$ & 1 & 18 & - & 132 & 37 & 4 & 27 & 141 & 81 & 53 \\
\hline $\begin{array}{l}\text { Stenopterobia delicatissima } \\
\text { (Lewis) Van Heurck }\end{array}$ & 30 & 11 & 44 & 48 & 28 & - & 10 & 8 & 6 & 5 \\
\hline Surirella robusta Ehrenberg & 6 & 9 & - & 33 & 5 & 一 & 39 & 15 & 5 & 5 \\
\hline Tabellaria sp. & - & 9 & 1 & - & 14 & 一 & - & 1 & 2 & - \\
\hline Total & 9,064 & 9,453 & 6,203 & 28,164 & 12,958 & 1,657 & 15,903 & 15,612 & 12,905 & 15,115 \\
\hline
\end{tabular}


TABLE II

Frequency of organisms (semi-permanent slides) in the stomach contents of Simulium perflavum (Diptera: Simuliidae) larvae in five streams in Central Amazônia, in the dry (Sept./Oct. 1996) and rainy seasons (Feb./ Mar. 1997)

\begin{tabular}{|c|c|c|c|c|c|c|c|c|c|c|}
\hline \multirow[t]{2}{*}{ Organisms observed } & \multicolumn{2}{|c|}{ Bueiro } & \multicolumn{2}{|c|}{ ZF3 } & \multicolumn{2}{|c|}{ Cemitério } & \multicolumn{2}{|c|}{ Escada } & \multicolumn{2}{|c|}{ Ibama } \\
\hline & Dry $\mathrm{F}$ & Rainy & Dry & Rainy & Dry & Rainy & Dry 1 & Rainy & Dry 1 & Rainy \\
\hline ctinotaenium curcubita (Bréb.) Teiling & - & 1 & - & - & - & - & - & - & - & - \\
\hline nium globo & - & - & - & - & 1 & 1 & 1 & - & 1 & 3 \\
\hline ctinotaenium sp. & - & - & - & - & - & - & 2 & - & - & - \\
\hline tinotaenium wollei Kütz & - & - & - & - & - & - & 1 & - & 1 & - \\
\hline nabaena sp. & - & - & - & - & 1 & - & - & - & - & - \\
\hline Bambusina brebis & 1 & 1 & 91 & 125 & - & - & - & - & 5 & 12 \\
\hline $\operatorname{Cos} n$ & - & - & - & - & - & - & - & - & 1 & 1 \\
\hline Closterium sp. & 2 & 3 & 44 & 41 & 6 & 4 & 112 & 22 & 74 & 26 \\
\hline Clo & - & - & 3 & 1 & - & - & 32 & 9 & 2 & - \\
\hline & - & - & - & 1 & - & 1 & 1 & - & - & - \\
\hline Clos & - & - & - & - & - & - & 1 & 1 & 2 & - \\
\hline Clost & - & - & - & - & - & - & 2 & 1 & 1 & - \\
\hline Clo & - & - & - & - & - & - & - & 7 & 4 & - \\
\hline & - & - & 1 & 3 & - & - & - & - & - & - \\
\hline Des & - & - & - & - & - & - & - & - & - & 2 \\
\hline esmidium & - & - & - & - & - & - & - & - & 1 & - \\
\hline$u a$ & - & 1 & - & - & - & - & - & 1 & - & 1 \\
\hline & 1 & - & - & - & - & - & - & - & - & - \\
\hline Eugle & 1 & - & 1 & - & - & - & - & - & 1 & - \\
\hline sson) Kütz & - & - & 1 & - & - & - & - & - & - & - \\
\hline uno & - & - & 1 & - & 3 & - & 1 & - & - & - \\
\hline 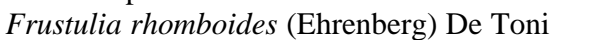 & 1 & - & - & - & - & - & 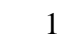 & 5 & 1 & - \\
\hline 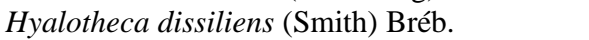 & 1 & - & - & - & - & - & - & - & 787 & 190 \\
\hline$H$ & 2 & 7 & - & 1 & 1 & - & 1 & 2 & 1,440 & 402 \\
\hline & 3 & 7 & 202 & 492 & 1 & 3 & 193 & 4 & 258 & 277 \\
\hline Мic & - & - & - & 1 & - & - & 2 & - & 1 & - \\
\hline & - & - & 2 & - & - & - & - & - & - & - \\
\hline & - & - & - & - & - & - & 1 & - & - & - \\
\hline Ralf & - & - & - & - & - & - & 1 & 4 & 3 & \\
\hline$O{ }_{L u}$ & - & 1 & - & 20 & - & - & - & - & - & - \\
\hline $\mathrm{Nav}$ & 1 & - & - & - & - & - & 2 & - & - & - \\
\hline & - & - & - & - & - & - & - & - & 3 & - \\
\hline$O$ & 68 & 81 & 4 & 48 & 4 & 1 & 7 & 6 & 79 & 115 \\
\hline & 1 & - & - & 1 & - & - & 24 & 2 & - & - \\
\hline & 1 & - & 1 & 3 & - & - & - & - & - & - \\
\hline Pleu & 1 & 2 & - & - & 28 & - & 4 & 7 & - & 2 \\
\hline Pleur & 4 & 3 & 7 & 8 & 16 & 5 & 4 & 1 & 5 & \\
\hline Pleu & 1 & - & 1 & - & 20 & - & 3 & - & - & - \\
\hline & - & - & - & 2 & - & - & - & - & - & - \\
\hline$S p$ & - & - & - & - & - & - & - & 1 & - & - \\
\hline Spy & 1 & 1 & 87 & 8 & - & - & 13 & 4 & 17 & 35 \\
\hline W. Smith & 1 & - & - & - & - & - & - & - & - & - \\
\hline & 3 & - & - & - & - & - & 1 & - & - & - \\
\hline & 1 & 1 & 4 & 4 & - & 3 & 1 & - & - & - \\
\hline Tetn & - & - & - & 1 & - & - & - & - & - & - \\
\hline & - & - & - & 5 & - & - & - & - & - & - \\
\hline lii Grönblad \& Croasdale & - & - & 3 & 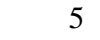 & - & - & - & - & 2 & - \\
\hline Xanthidium sp. & - & - & - & 3 & - & - & - & - & 1 & - \\
\hline Lecane (Monostyla) quadridentata Ehrenberg & 1 & - & - & 1 & - & - & - & - & - & - \\
\hline Total & 96 & 109 & 453 & 774 & 81 & 18 & 411 & 77 & 2,690 & 070 \\
\hline
\end{tabular}

-: absence 
similar to the plankton than to the periphyton. However, organisms found in the periphyton also were similar to the plankton (45.6\%), possibly because the periphyton detached from the substrate and entered the water column.

Correlations based on qualitative data on items in the stomach contents, plankton and periphyton agree with the Sorensen coefficient. The correlations between the stomach content organisms and the plankton and between the plankton and the pe- riphyton were significant ( $\mathrm{z}$ test, $\mathrm{p}<0.05$ ), while the correlation between stomach contents and periphyton was not significant ( $\mathrm{z}$ test, $\mathrm{p}>0.05$ ) (Table IV).

Based on the organisms found in the stomach contents of black fly larvae, the sampled streams can be divided into two groups with $77 \%$ similarity. The first group was composed of the Bueiro and ZF3 streams, and the second of the Cemiterio, Escada and Ibama streams, being the latter group less similar to the other streams (Fig. 74).

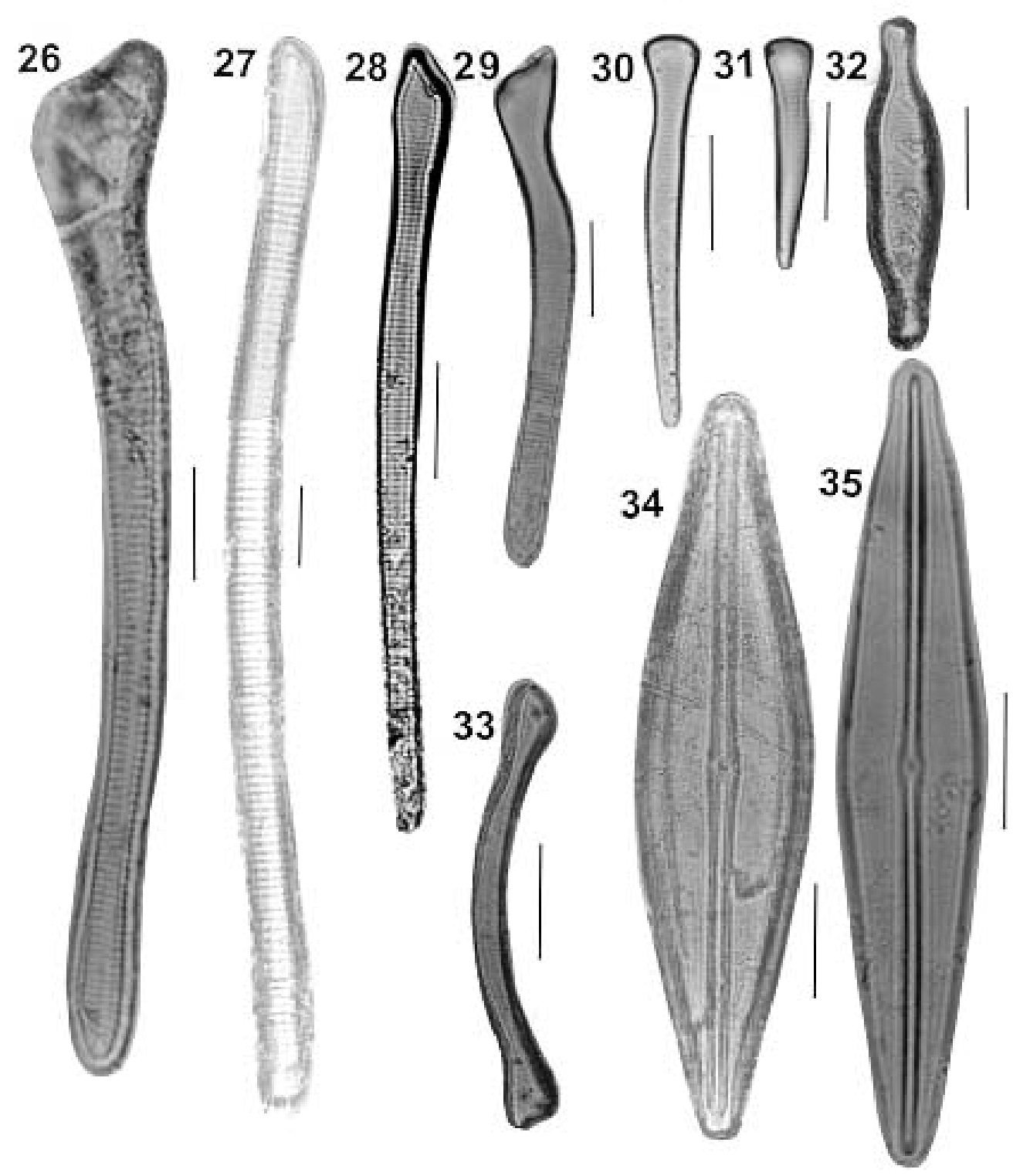

Fig. 26: Actinella brasiliensis. Fig. 27: A. robusta. Figs 28-29: A. brasiliensis. Figs 30-31: A. peronioides. Fig. 32: Fragilaria javanica. Fig. 33: A. punctata. Fig. 34: F. rhomboides. Fig. 35: F. crassinervia. Bar $=10 \mu \mathrm{m}$ 
Considering the geographical proximity of the studied streams we observed that they have geological, pedological and climatic characteristics in common. The Bueiro and Ibama streams belong to the Tarumã River Basin, ZF3 stream belong to the Rio Preto da Eva River Basin while Cemitério and Escada streams belong to the Urubu River Basin. This grouping result may be an indication that, even though the studied streams were disturbed by anthropogenic influences, they maintained characteristics of the hydrographic basins to which they belong, reflected in the composition

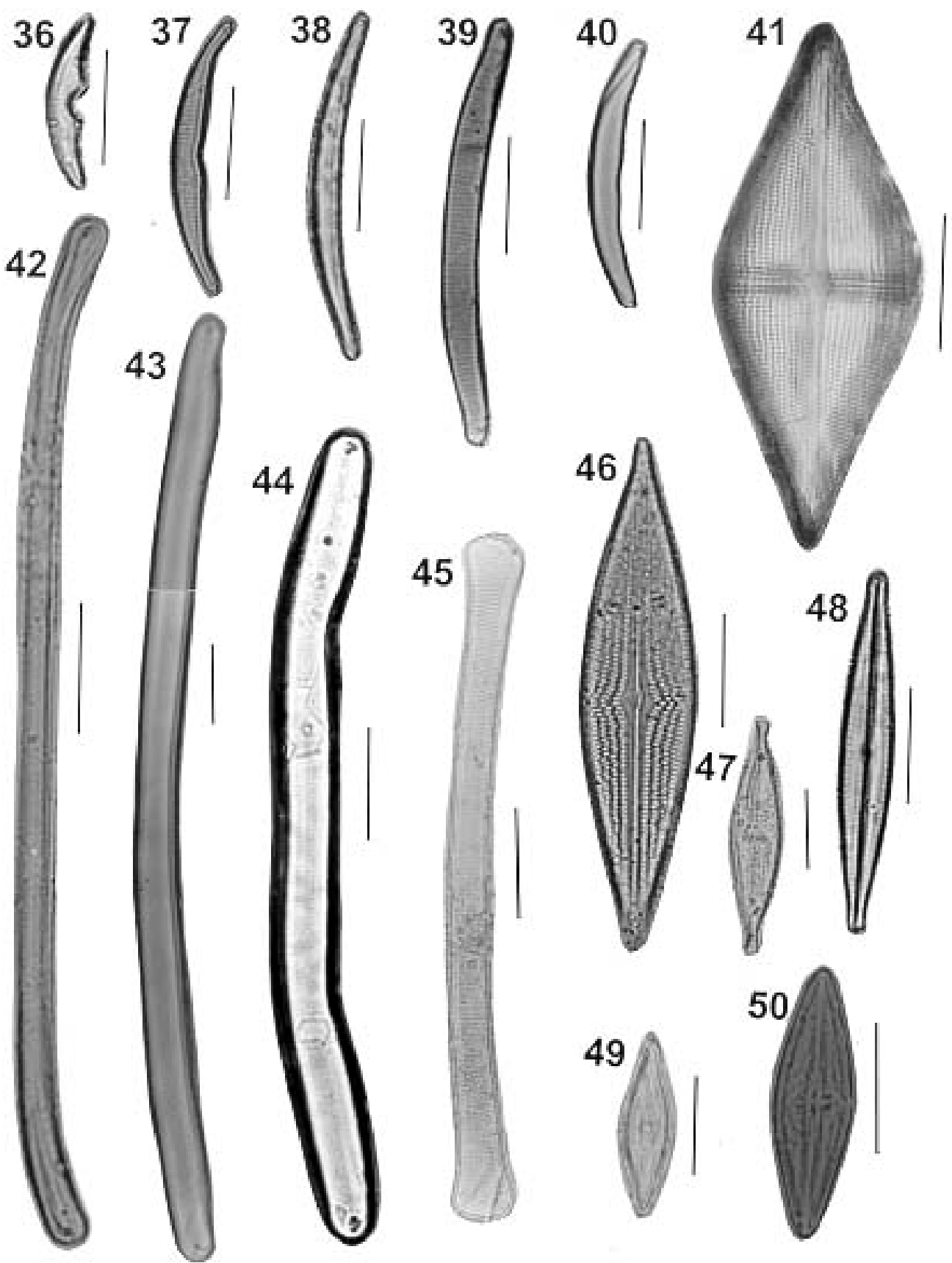

Figs 36-40: Eunotia bilunaris. Fig. 41: Brachysira kuntzei. Fig. 42: E. conversa. Figs 43-45: E. flexuosa. Fig. 46: Brachysira serians. Fig. 47: B. vitrea. Fig. 48: N. cryptocephala. Fig. 49: B. serians var. brachysira. Fig. 50: B. serians. Bar $=10 \mu \mathrm{m}$ 
of the phycoflora. Many workers have found that the classes of food items in the stomach contents of black fly larvae reflect, in general, the items available in the environment (e.g. Wotton 1977, Kurtak 1979).

Knowledge of black fly food items can provide important information on larval nutrition and help to clarify differences observed in population productivity of larvae in different habitats (Colbo 1982). More studies will be necessary, not only on larval feeding, but also on the ecological associations between breeding places, black fly larvae, plankton and periphyton, in order to improve our understanding of black fly bioecology.

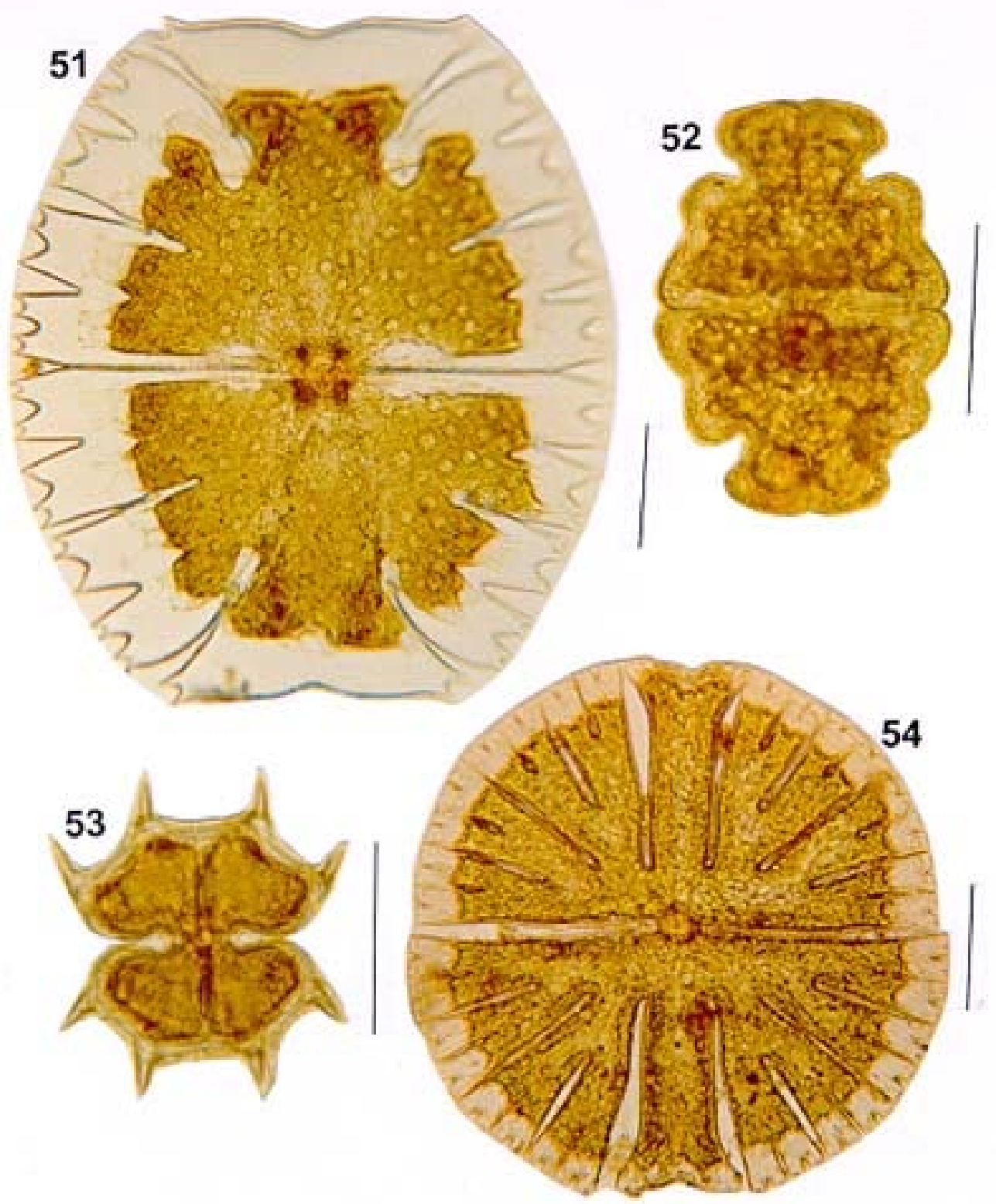

Fig. 51: Micrasterias truncata. Fig. 52: Euastrum sinuosum. Fig. 53: Xanthidium siolii. Fig. 54: M. radiosa . Bar $=50 \mu \mathrm{m}$ 
TABLE III

Presence (X) or absence (-) in the plankton and periphyton samples and stomach contents of Simulium perflavum (Diptera: Simuliidae) larvae collected in five streams in Central Amazonia, observed in the study period (Sep./ Oct. 1996 and Feb./Mar. 1997)

\begin{tabular}{|c|c|c|c|}
\hline & Plankton & Periphyton & Food items \\
\hline Cyanophyta & & & \\
\hline Anabaena sp. & $\mathrm{X}$ & - & $\mathrm{X}$ \\
\hline Aphanotece sp. & $\mathrm{X}$ & - & - \\
\hline Chroococus turgidus (Kützing) Nägeli & $\mathrm{X}$ & - & - \\
\hline Hapalosiphon sp. & $\mathrm{X}$ & - & - \\
\hline Merismopedia sp. & $\mathrm{X}$ & - & - \\
\hline Oscillatoria sancta (Küetzing) Gomont & $\mathrm{X}$ & - & - \\
\hline Oscillatoria sp. & $\mathrm{X}$ & - & $\mathrm{X}$ \\
\hline Pseudoanabaena sp. & - & - & $X$ \\
\hline Euglenophyta & & & \\
\hline Euglena acus Ehrenberg & $\mathrm{X}$ & - & $\mathrm{X}$ \\
\hline Trachelomonas armata (Ehrenberg) Stein & $X$ & - & - \\
\hline Bacillariophyta & & & \\
\hline Achnanthes sp. & - & - & $\mathrm{X}$ \\
\hline Actinella brasiliensis Grun. & - & - & $\mathrm{X}$ \\
\hline Actinella mirabilis Grun. & $\mathrm{X}$ & $\mathrm{X}$ & - \\
\hline Actinella punctata Lewis & - & - & $\mathrm{X}$ \\
\hline Actinella peronioides Hustedt & $\mathrm{X}$ & $X$ & $\mathrm{X}$ \\
\hline Actinella guianensis Grun. & $\mathrm{X}$ & $\mathrm{X}$ & - \\
\hline $\begin{array}{l}\text { Brachysira serians (Brebisson) Round \& Mann var. brachysira } \\
\text { (Hust.) Cox. }\end{array}$ & - & - & $\mathrm{X}$ \\
\hline Brachysira serians (Brebisson) Round \& Mann & $\mathrm{X}$ & $\mathrm{X}$ & $\mathrm{X}$ \\
\hline Brachysira vitrea (Grun.) Ross & $\mathrm{X}$ & $\mathrm{X}$ & $\mathrm{X}$ \\
\hline Brachysira kuntzei (Reichelt) Metzeltin \& Lange-Bertalot & - & - & $\mathrm{X}$ \\
\hline Cyclotella sp. & - & - & $\mathrm{X}$ \\
\hline Cymbella difficilis Kraske & - & - & $\mathrm{X}$ \\
\hline Cymbella minuta Hilse & - & - & $\mathrm{X}$ \\
\hline Cymbella sp. & - & - & $\mathrm{X}$ \\
\hline Dinobryon sertularia Ehrenberg & $\mathrm{X}$ & $\mathrm{X}$ & - \\
\hline Eunotia sp. & - & - & $\mathrm{X}$ \\
\hline Eunotia bidentula W. Smith & - & - & $\mathrm{X}$ \\
\hline Eunotia flexuosa (Brébisson) Kütz. & $\mathrm{X}$ & $\mathrm{X}$ & $\mathrm{X}$ \\
\hline Eunotia gibbosa Grunov & $\mathrm{X}$ & - & $\mathrm{X}$ \\
\hline Eunotia robusta Ralfs & $\mathrm{X}$ & - & - \\
\hline Eunotia bilunaris (Ehrenberg) Mills & $\mathrm{X}$ & $\mathrm{X}$ & $\mathrm{X}$ \\
\hline Eunotia sudetica $\mathrm{O}$. Müller & $\mathrm{X}$ & - & $\mathrm{X}$ \\
\hline Eunotia maior (W. Smith) Rabh. & - & - & $\mathrm{X}$ \\
\hline Eunotia minor (Kützing) Grunow & - & - & $\mathrm{X}$ \\
\hline Eunotia serra Ehrenberg & - & - & $\mathrm{X}$ \\
\hline Eunotia triodon Ehrenberg & $\mathrm{X}$ & $\mathrm{X}$ & - \\
\hline Eunotia trigibba Hustedt & - & - & $\mathrm{X}$ \\
\hline Eunotia zygodon Ehrenberg & $\mathrm{X}$ & - & $\mathrm{X}$ \\
\hline Eunotia conversa Hustedt & $\mathrm{X}$ & $\mathrm{X}$ & $\mathrm{X}$ \\
\hline Fragilaria javanica Hustedt & - & - & $\mathrm{X}$ \\
\hline Frustulia crassinervia (Bréb.) Lange-Bertalot \& Krammer & - & $\mathrm{X}$ & $\mathrm{X}$ \\
\hline Frustulia rhomboides (Ehrenberg ) De Toni & $\mathrm{X}$ & $\mathrm{X}$ & $\mathrm{X}$ \\
\hline Gomphonema gracile Ehrenberg & $\mathrm{X}$ & $\mathrm{X}$ & $\mathrm{X}$ \\
\hline Gomphonema sp. Ehrenberg. & $\mathrm{X}$ & $\mathrm{X}$ & $\mathrm{X}$ \\
\hline Aulacoseira sp. & $\mathrm{X}$ & - & - \\
\hline Navicula sp. & $\mathrm{X}$ & $\mathrm{X}$ & $\mathrm{X}$ \\
\hline Navicula cryptocephala Kützing & - & - & $\mathrm{X}$ \\
\hline Navicula subtilissima Cleve & - & - & $\mathrm{X}$ \\
\hline Navicula parasubtilissima Kobayasi \& Nagumo & - & - & $\mathrm{X}$ \\
\hline Pinnularia maior (Kützing) Rabenhout & - & $\mathrm{X}$ & $\mathrm{X}$ \\
\hline Pinnularia subcapitata Gregory & - & - & $\mathrm{X}$ \\
\hline Pinnularia streptoraphe Cleve & - & - & $\mathrm{X}$ \\
\hline Pinnularia sp. & $\mathrm{X}$ & - & $\mathrm{X}$ \\
\hline Peronia brasiliensis Hustedt & $\mathrm{X}$ & $\mathrm{X}$ & $\mathrm{X}$ \\
\hline Stauroneis sp. & $\mathrm{X}$ & - & - \\
\hline Stenopterobia curvula (W. Smith) Krammer & $\mathrm{X}$ & $\mathrm{X}$ & $\mathrm{X} \downarrow$ \\
\hline
\end{tabular}


Stenopterobia delicatissima (Lewis) Van Heurck

Stenopterobia intermedia Lewis

Surirella linearis W. Smith

Surirella robusta Ehrenberg

Surirella sp.

Synedra sp.

Fragilaria sp.

Tabellaria sp.

Plankton
$\bar{X}$
X
X
-
X
X
X

\begin{tabular}{cc} 
Periphyton & Food items \\
\hline $\bar{X}$ & $\bar{X}$ \\
- & $\mathrm{X}$ \\
- & $\mathrm{X}$ \\
- & $\mathrm{X}$ \\
$\mathrm{X}$ & - \\
$\mathrm{X}$ & $\bar{X}$
\end{tabular}

Rhodophyta

Audouinella violaceae (Kütz) Hamel

Batrachospermum moniliferum Roth

$X$
$X$

Dinophyta

Peridinium sp.

$\mathrm{X}$

Chlorophyta

Actinotaenium curcubita (Bréb.) Teiling

Actinotaenium globosum (Bulnheim) Teiling

Actinotaenium sp.

Actinotaenium tumidum (Gronbl.) Teiling

Actinotaenium wollei Kütz.

Bambusina brebissonii Küetz.

Closteriopsis sp.

Closterium sp.

Closterium dianai Ehrenberg

Closterium gracile Brébisson

Closterium kuetzingii Brébisson

Closterium libellula Forcke

Closterium macilentum Brébisson

Closterium navicula (Bréb.) Lütkemüller

Closterium pronum Brébisson

Closterium regulare Brébisson

Closterium setaceum Ehrenberg

Closterium subulatum (Kütz.) Bréb.

Closterium tumidum Johnson

Cosmarium incrassatum (Fritsch \& Rich)

Cosmarium pseudoconnatum Nordstedt

Cosmarium siolii Forster

Cosmarium sp.

Desmidium laticeps Nordstedt

Desmidium cylindricum Greville

Desmidium grevelli (Kütz.) DeBary

Desmidium quadratum Nordstedt

Desmidium elegans (Racib.) Grönblad.

Desmidium sp.

Euastrum sp.

Euastrum brasiliensis Borge

Euastrum sinuosum Lenorm

Hyalotheca $\mathrm{sp}$.

Hyalotheca dissiliens (Smith) Bréb.

Micrasterias borgei Krieger

Micrasterias radiosa Ralfs

Micrasterias rotata (Greville) Ralfs

Micrasterias siolii Scott \& Croasdale

Micrasterias truncata (Corda) Brébisson

X

X

Micrasterias torreyi Bailey

Micrasterias sp.

Microspora sp.

Mougeotia sp.

Netrium sp.

Oedogonium $\mathrm{sp}_{1}$.

Oedogonium $\mathrm{sp}_{2}$.

Plerotaenium tridentulum Grönblad \& Croasdale

Pleurotaenium coronatum (Bréb.) Rabenhorst

Pleurotaenium minutum (Ralfs) Delp.

Pleurotaenium sp.

\begin{tabular}{|c|c|c|}
\hline$X$ & $X$ & $X$ \\
\hline$X$ & - & $X$ \\
\hline$X$ & $X$ & $X$ \\
\hline$X$ & - & - \\
\hline$X$ & $X$ & $X$ \\
\hline$X$ & $X$ & $X$ \\
\hline$X$ & - & - \\
\hline$X$ & $X$ & $X$ \\
\hline$X$ & $X$ & $X$ \\
\hline- & $X$ & - \\
\hline$X$ & $X$ & - \\
\hline$X$ & $\mathrm{X}$ & - \\
\hline$X$ & $X$ & - \\
\hline$X$ & - & $X$ \\
\hline$X$ & - & $X$ \\
\hline$X$ & $\bar{v}$ & $X$ \\
\hline X & X & - \\
\hline$X$ & $\mathrm{X}$ & $X$ \\
\hline $\mathbf{Y}$ & $X$ & - \\
\hline X & - & \\
\hline X & - & 二 \\
\hline $\begin{array}{l}X \\
X\end{array}$ & $\bar{X}$ & $\bar{X}$ \\
\hline$X$ & - & - \\
\hline X & - & X \\
\hline X & - & - \\
\hline$X$ & - & $\bar{v}$ \\
\hline $\mathrm{y}$ & $\bar{y}$ & X \\
\hline$\underline{X}$ & $\begin{array}{l}X \\
X\end{array}$ & $\begin{array}{l}X \\
X\end{array}$ \\
\hline - & $\mathrm{X}$ & - \\
\hline$X$ & - & $X$ \\
\hline$X$ & $X$ & $X$ \\
\hline$\overline{5}$ & - & $X$ \\
\hline$X$ & $\overline{\mathrm{X}}$ & $\overline{\mathrm{X}}$ \\
\hline $\begin{array}{l}X \\
X\end{array}$ & $\mathrm{X}$ & $\hat{x}$ \\
\hline$X$ & $X$ & - \\
\hline$X$ & - & - \\
\hline- & - & $\mathrm{X}$ \\
\hline X & $\overline{\mathrm{y}}$ & X \\
\hline $\begin{array}{l}\lambda \\
X\end{array}$ & $X$ & X \\
\hline & - & $\begin{array}{l}X \\
X\end{array}$ \\
\hline$X$ & $X$ & $\mathrm{X}$ \\
\hline X & - & - \\
\hline$X$ & - & - \\
\hline $\mathrm{X}$ & $\bar{v}$ & $\bar{v}$ \\
\hline$X$ & X & $X$ \\
\hline$X$ & $X$ & X \\
\hline
\end{tabular}




\begin{tabular}{lccc}
\hline & Plankton & Periphyton & Food items \\
\hline Pleurotaenium trabecula (Ehrenberg) Nägeli & $\mathrm{X}$ & $\overline{\mathrm{X}}$ & $\mathrm{X}$ \\
Spirogyra sp. & $\mathrm{X}$ & - & $\mathrm{X}$ \\
Spondylosium sp. & $\overline{\mathrm{X}}$ & - & - \\
Staurastrum quadrangulare Brébisson & $\mathrm{X}$ & $\overline{\mathrm{X}}$ & - \\
Staurastrum setigerum Cleve & $\mathrm{X}$ & $\overline{\mathrm{X}}$ & $\overline{\mathrm{X}}$ \\
Staurastrum sp. & $\mathrm{X}$ & $\mathrm{X}$ & $\mathrm{X}$ \\
Staurodesmus sp. & $\mathrm{X}$ & $\overline{\mathrm{X}}$ & $\overline{\mathrm{X}}$ \\
Tetmemorus laevis (Kützing) Ralfs & $\mathrm{X}$ & $\overline{\mathrm{X}}$ \\
Tetmemorus granulatus (Bréb.) Ralfs & $\mathrm{X}$ & $\mathrm{X}$ & $\mathrm{X}$ \\
Xanthidium amazonense Scott \& Croasdale & $\overline{\mathrm{X}}$ & $\mathrm{X}$ & - \\
Xanthidium siolii Grönblad \& Croasdale & $\mathrm{X}$ & & \\
Xanthidium canadense (Joshua) Forster & & $\mathrm{X}$ \\
Xanthidium sp. & $\mathrm{X}$ & $\mathrm{X}$ \\
Zygnema sp. & & & \\
Rotifera & & &
\end{tabular}

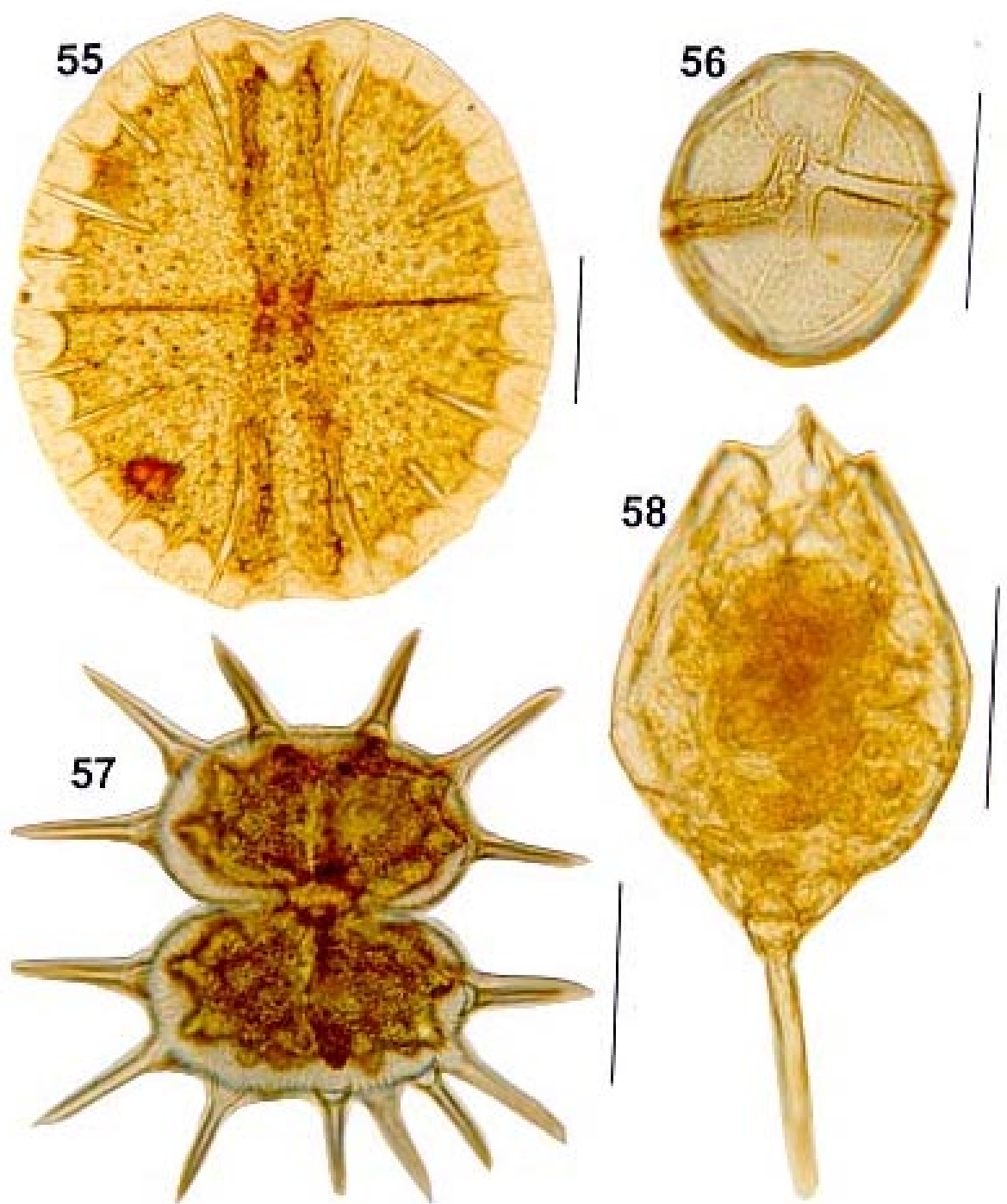

Fig. 55: Micrasterias rotata. Fig. 56: Peridinium sp. Fig. 57: Xanthidium amazonense. Fig. 58: Lecane quadridentata . Bar $=50 \mu \mathrm{m}$ 


\section{TABLE IV}

Correlation coefficient ( $\mathrm{r}$ ) and significance test ( $\mathrm{z}$ value) between the organisms present in the stomach contents of Simulium perflavum (Diptera: Simuliidae) larvae, plankton and periphyton

\begin{tabular}{lccc}
\hline & $\mathrm{r}$ & $\mathrm{z}$ value & $\mathrm{n}$ \\
\hline Stomach content x plankton & -0.34 & $-3.85^{a}$ & 131 \\
Stomach content x periphyton & 0.06 & 0.70 & 131 \\
Plankton x periphyton & 0.25 & $2.81^{a}$ & 131 \\
\hline
\end{tabular}

a: $\mathrm{p}<0.05$

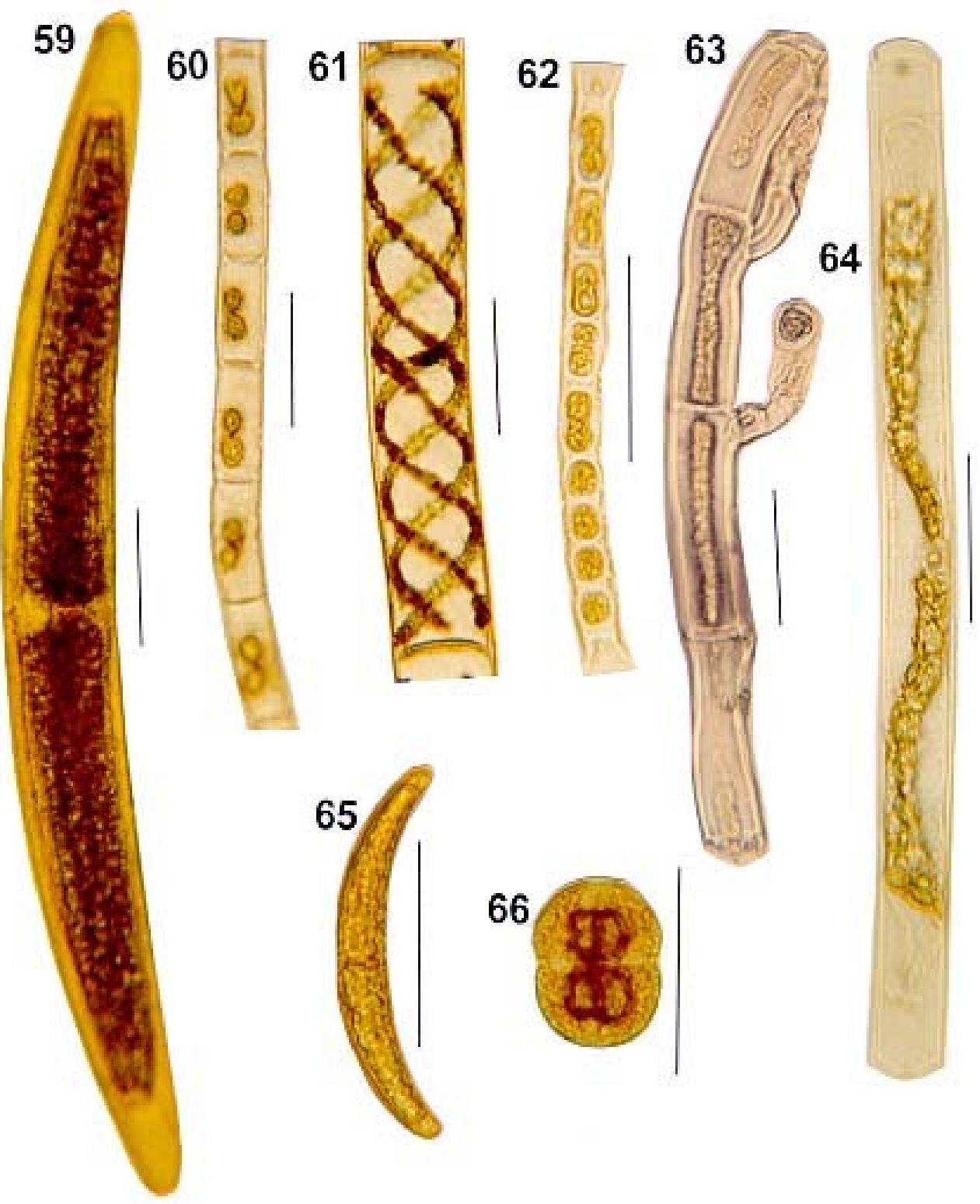

Fig. 59: Closterium regulare. Fig. 60: Hyaloteca sp. Fig. 61: Spirogyra sp. Fig. 62: Microspora sp. Fig. 63: Audouinella violaceae. Fig. 64: Mougeotia sp. Fig. 65: Closterium sp. Fig. 66: Actinotaenium wollei. Bar $=50 \mu \mathrm{m}$ 


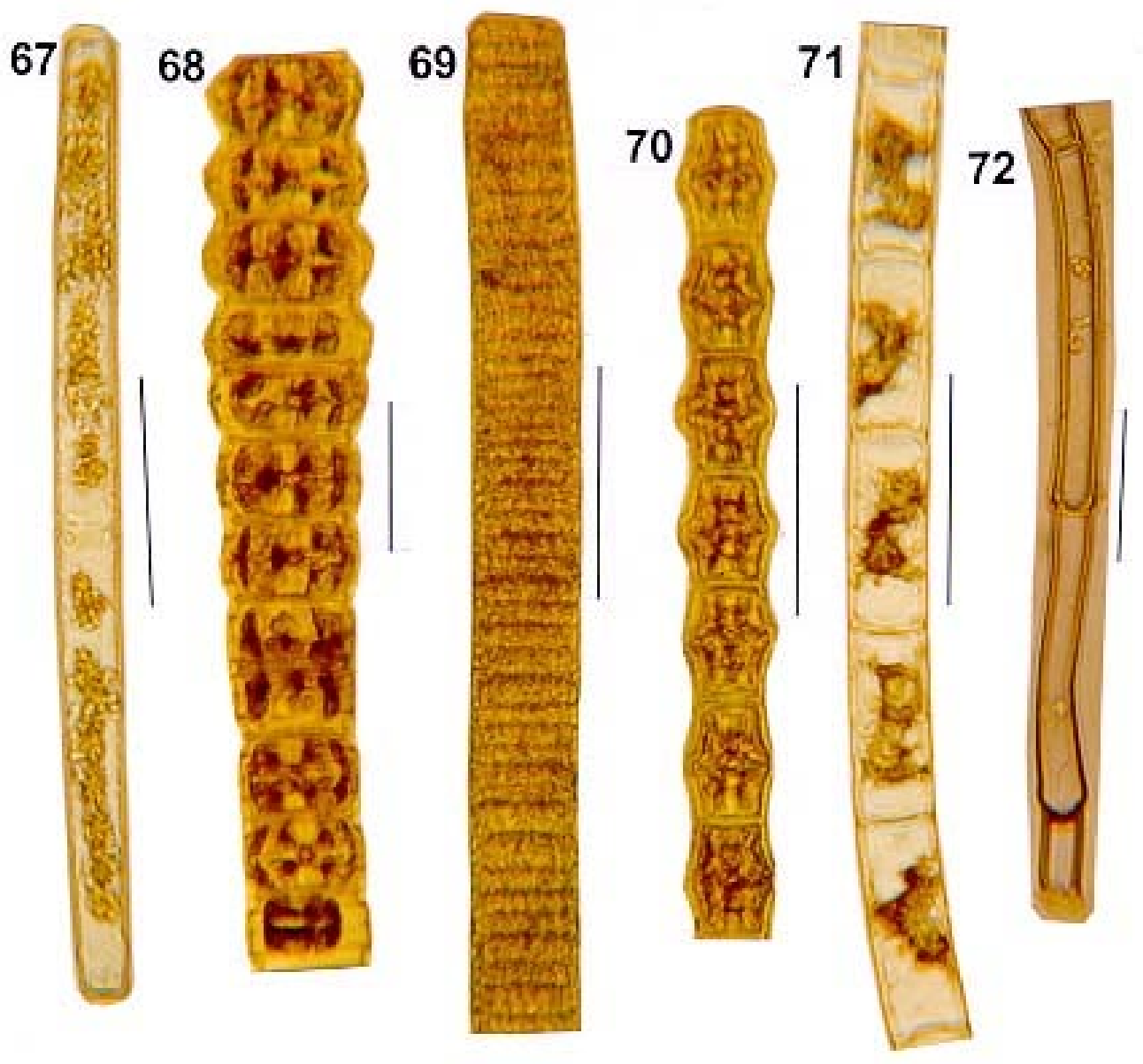

Fig. 67: Pleurotaenium sp. Fig. 68: Desmidium cylindricum. Fig. 69: Oscillatoria sp. Fig. 70: Bambusina brebissonii. Fig. 71: Zygnema sp. Fig. 72: Oedogonium sp. Bar $=50 \mu \mathrm{m}$

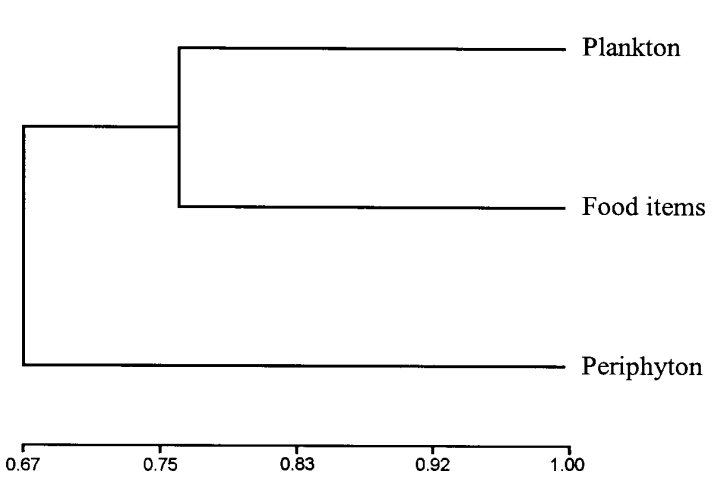

Fig. 73: similarity dendrogram between the organisms in the stomach contents of Simulium perflavum (Diptera: Simuliidae) larvae and the food availability in the habitat (plankton and periphyton) (Sorensen coefficient, UPGMA)

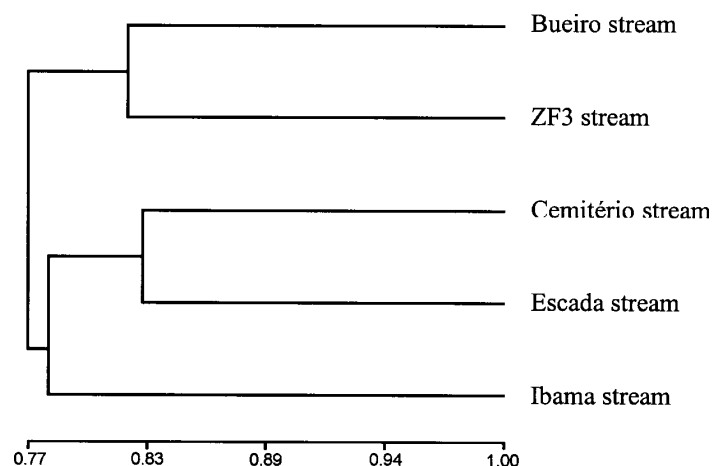

Fig. 74: similarity dendrogram between five streams in relation to the organisms in the stomach contents of Simulium perflavum (Diptera: Simuliidae) larvae (Sorensen coefficient, UPGMA) 


\section{ACKNOWLEDGMENTS}

To the master's students of Laboratório de Ficologia, UFPR and Dr PS Mera for helping to identify the microalgae; Dr Mera also helped with the photographs presented in this paper. To MSc. Marcelo Garcia who made helpful suggestions in many steps of this project and Dr PM Fearnside, who made helpful suggestions and revised the manuscript.

\section{REFERENCES}

Araújo VC 1970. Fenologias de essências florestais amazônicas. Bol INPA, Pesquisas Florestais 4: $1-25$.

Bourrelly P 1968. Les Algues d'Eau Douce, Initiation à la Systematique, Tom. II, Les Algues Jaunes et Brunes, N. Boubée \& Cie, Paris, 438 pp.

Bourrelly P 1970. Les Algues d'Eau Douce, Initiation à la Systematique, Tom. III, Les Algues Blues et Rouges, N. Boubée \& Cie, Paris, 512 pp.

Bourrelly $\mathrm{P} 1972$. Les Algues d'Eau Douce, Initiation à la Systematique, Tom. I, Les algues Vertes, N. Boubée \& Cie, Paris, 569 pp.

Burton GJ 1973. Feeding of Simulium hargreavesi Gibbins larvae on Oedogonium algal filaments in Ghana. J Med Ent 10: 101-106.

Colbo MH 1982. Size and fecundity of adult Simuliidae (Diptera) as a function of stream habitat, year and parasitism. Can J Zool 60: 2507-2513.

Cox EJ 1996. Identification of Freshwater Diatoms from live Material, Chapman \& Hall, London, 158 pp.

Craig DA 1977. Mouthparts and feeding behavior of Tahitian larval Simuliidae (Diptera: Nematocera). Quaest Entomol 13: 195-218.

Dellome Filho J 1989. Simuliofauna do rio Marumbi, Morretes, PR, Brasil. Microalgas como alimento de larvas de Simulium incrustatum Lutz, 1910 (Diptera, Simuliidae). Mem Inst Oswaldo Cruz 84(Suppl. IV): 157-163.

Dudley TL, Cooper SD, Hemphill N 1986. Effects of macroalgae on a stream invertebrate community. $N$ Am Bentholol Soc 5: 93-106.

Fredeen FJH 1964. Bacteria as food for blackfly larvae (Diptera:Simuliidae) in laboratory cultures and in natural streams. Can J Zool 42: 527-548.

Hustedt F 1930. Bacillariophyta (Diatomeae). In A Pascher, Die Susswasser-flora Mitteleuropas, Iena, Gustav Fisher, Heft 10, 466 pp.

Kobayasi H, Nagumo T 1988. Examination of the type materials of Navicula subtilissima Cleve (Bacillariophyceae). Bot Mag Tokyo 101: 239-253.

Krammer K, Lange-Bertalot H 1985. Naviculaceae: neue und Wening bekannte Taxa, neue Kombination und Synonyme Sowie Bernekungen zu einigen Gattungen. Bibl Diatomol Berlin 9: 5-230.

Krammer K, Lange-Bertalot H 1986. Bacillariophyceae: Naviculaceae. In H Ettl, J Gerloff, H Heyning, D Mollenhauer (eds), Süsswasserflora von Mitteleuropa, Vol. 2, part. 1, G. Fischer, Stuttgart, 876 pp.

Krammer K, Lange-Bertalot H 1988. Bacillariophyceae: Bacillariaceae, Epithemiaceae, Surirellaceae. In HEttl,
J Gerloff, H Heyning, D Mollenhauer (eds), Süsswasserflora von Mitteleuropa, Vol. 2, part. 2, G. Fischer, Stuttgart, 595 pp.

Krammer K, Lange-Bertalot H 1991a. Bacillariophyceae: Centrales, Fragilariaceae, Eunotiaceae. In H Ettl, J Gerloff, H Heyning, D Mollenhauer (eds), Süsswasserflora von Mitteleuropa, Vol. 2, part. 3, G. Fischer, Stuttgart, 576 pp.

Krammer K, Lange-Bertalot H 1991b. Bacillariophyceae: Achnanthaceae. Kristische Ergänzungen zu Navicula (Lineolatae) und Gomphonema. In H Ettl, J Gerloff, H Heyning, D Mollenhauer (eds), Süsswasserflora von Mitteleuropa, Vol. 2, part.4, G. Fischer, Stuttgart, $437 \mathrm{pp}$.

Kurtak DC 1978. Efficiency of filter feeding of black fly larvae (Diptera: Simuliidae). Can J Zool 56: 1608-1623.

Kurtak DC 1979. Food of black fly larvae (Diptera:Simuliidae): Seasonal changes in gut contents and suspended material at several sites in a single watershed. Quaest Ent 15: 357-374.

Kuznetsov AV 1981. The diet of black fly larvae (Diptera: Simuliidae). Rev Appl Entomol 69: 134.

Lacey LA, Lacey JM 1983. Filter feeding of Simulium fulvinotum (Diptera:Simuliidae) in the Central Amazon Basin. Quaest Entomol 19: 41-51.

Lozovei AL 1989. Diatomáceas (Bacillariophyceae) como alimento das larvas de Simulium spp. (Diptera, Simuliidae) no rio Passaúna, Curitiba, Paraná, Brasil. Arq Biol Tecnol 32: 339-376.

Lozovei AL, Luz E 1976. Diptera Culicidae em Curitiba e arredores. II. Alimentação. Arq Biol Tecnol 19: 43-84.

Moreira Filho H, Valente Moreira IM 1981. Avaliação taxonômica e ecológica das diatomáceas (Bacillariophyceae) epífitas em algas pluricelulares obtidas nos litorais dos estados do Paraná, Santa Catarina e São Paulo. Bol Museu Botânico Municipal 47: $1-17$.

Peterson BV 1956. Observations on the biology of Utah black flies (Diptera:Simuliidae). Can Entomol 88: 496-507.

Patrick R, Reimer W 1966. The Diatoms of the United States, Vol. 2, The Livingston Publishing Company, $213 \mathrm{pp}$.

Pielou EC 1984. The Interpretation of Ecologycal Data, John Wiley \& Sons, New York, 263 pp.

Sioli H 1965. A limnologia e a sua importância em pesquisas da Amazônia. Amazoniana 1: 11-35.

Thompson BH 1987. The use of algae as food by larval Simuliidae (Diptera) of Newfoundland streams. III. Growth of larvae reared on different algal and other foods. Arc Hydrobiol/Suppl. 76: 459-466.

Wotton RS 1977 . The size of particles ingested by moorland stream blackfly larvae (Simuliidae). Oikos 29: 332-335.

Wotton RS 1980. Bacteria as food for blackfly larvae (Diptera: Simuliidae) in a lake-outlet in Finland. Ann Zool Fennici 17: 127-130.

Zar HJ 1996. Biostatistical Analysis, Prentice-Hall do Brasil, Rio de Janeiro, 662 pp. 